\title{
DIAGNOSA PENYAKIT PADA IKAN AIR TAWAR DENGAN METODE RULE-BASED DAN CASE BASED REASONING
}

\author{
Hisma Abduh ${ }^{1)}$ \\ ${ }^{1)}$ Dosen Program Studi Teknik Informatika, Universitas Andi Djemma, Palopo \\ 1) isma.syakirah@gmail.com
}

\begin{abstract}
Abstrak
Para pelaku usaha budidaya ikan air tawar, khususnya dalam pemeliharaan ikan di kolam air tawar sudah jelas dituntut agar apa yang diusahakan pada usaha pembesaran ikan dapat berkembang atau tumbuh dengan baik, cepat dan tumbuh besar sehingga produksi akan berhasil secara baik dan bisa memuaskan dengan keuntungan yang maksimal. Untuk mencapai hasil tersebut sudah jelas bahwa pelaku usaha perlu memahami beberapa teknik yang harus dijalankan sehingga apa yang dilakukan dalam usaha tersebut dapat berhasil dengan baik dan ikan bisa tumbuh berkembang secara cepat dan sempurna. Untuk menghambat kegagalan dalam pemeliharaan ikan maka perlu dibuat sebuah sistem pakar dengan menggunakan penggabungan RBR dan CBR. Sistem pakar dimulai dengan melakukan pengecekan data masukan berdasarkan aturan yang telah tersimpan dalam basis aturan dengan menerapkan metode certainty factor. Bersamaan dengan itu juga sistem akan melakukan pengecekan data input berdasarkan kasus yang tersimpan dalam basis kasus dengan menerapkan metode nearest neighbor. Hasil penelitian menghasilkan bahwa sistem mengenali 24 data yang sesuai dengan data riil hasil diagnosa pakar dan 6 data yang tidak sesuai dengan data riil hasil diagnosa pakar atau bisa dikatakan nilai akurasi sistem sebesar $80 \%$.
\end{abstract}

Kata kunci : rule-based reasoning, case-based reasoning, certainty factor, nearest neighbor, penyakit ikan air tawar.

\section{PENDAHULUAN}

Ikan merupakan hewan yang hidup di air yang menjadi salah satu dari sekian banyak bahan makanan yang dibutuhkan manusia, ikan sangat bermanfaat bagi manusia sebab didalamnya terdapat bermacam zat-zat yang dibutuhkan oleh tubuh manusia seperti : protein, vitamin A, vitamin B1 dan vitamin B2. Selain kebutuhan ikan bagi masyarakat sangatlah penting, maka sangat wajar jika usaha perikanan harus terus dipacu untuk dikembangkan. Pembangunan perikanan saat ini mengarahkan pengembangan usaha berbasis budidaya, karena berkurangnya hasil tangkapan dari perairan umum, sedangkan permintaan pasar semakin hari semakin meningkat (Anggraeni, T. D., Qomariyah dan Khalidah. 2015). Pemilihan jenis ikan yang akan dipelihara secara komersial hendaknya memperhatikan nilai ekonomi ikan, preferensi (kesukaan masyarakat terhadap suatu jenis ikan, kecepatan pertumbuhan ikan, daya tahan ikan terhadap perubahan lingkungan dan gangguan penyakit.

Permasalahan yang sering dihadapi dalam budidaya ikan adalah penyakit yang dapat menyebabkan menurunnya tingkat produksi ikan. Sumber penyakit yang dialami oleh ikan budidaya dapat berasal dari ikan itu sendiri, media, budidaya, dan pathogen (Afrianto, E., Liviawaty, E., Jamaris, Zafran., dan Hendi. 2015). Penyakit ikan merupakan hal yang tidak diinginkan bagi pembudidaya ikan, karena dapat menyebabkan panen tidak maksimal dan kematian massal pada ikan, akibatnya mereka mengalami banyak kerugian (Aristoteles, Wardiyanto dan Ardye Amando Pratama. 2015). Untuk mencegah atau mengendalikan timbulnya penyakit pada ikan budidaya, perlu dipahami dari mana sumber penyakit tersebut. Ketidaktahuan atau ketidakpedulian terhadap sumber penyakit sering mengakibatkan kerugian besar, terutama bila penyakit tersebut dapat menyebabkan kematian massal ikan yang dibudidaya. Dengan tidak adanya pengetahuan yang baik maka akan menimbulkan 
masalah baru yaitu penanganan yang salah terhadap suatu penyakit, maka akan menghasilkan hasil yang merugikan dalam usaha budidaya ikan air tawar. Sehingga dibutuhkan sebuah sistem yang dapat membantu para petambak atau petani ikan dan para praktisi bidang perikanan dalam menegakkan diagnosa penyakit yang menyerang.

Terdapat banyak metode yang dapat digunakan dalam pengembangan sebuah sistem pakar, khususnya dalam pengembangan sistem pakar dalam dunia media, baik menggunakan penalaran berbasis kasus (case based reasoning) maupun menggunakan penalaran berbasis pengetahuan (rule based reasoning). Baik case based reasoning (CBR) maupun rule based reasoning (RBR) merupakan metode yang populer digunakan dalam pembuatan sebuah sistem cerdas. Kombinasi dari kedua pendekatan ini dapat saling melengkapi dalam menyelesaikan masalah pada sebuah sistem (Made, H.P.S, and E. Winarko. 2011).

Representasi pengetahuan (knowledge representation) dari sebuah sistem RBR berdasaran aturan-aturan baku yang dapat di pertanggung jawabkan kebenaranya dari kepakaran dalam bidang tertentu. Metode yang digunakan dalam menghitung Sedangkan representasi pengetahuan sistem CBR berupa kumpulan kasus (case base) yang pernah terjadi sebelumnya. Selanjutnya dalam menyelesaikan suatu permasalahan, CBR menggunakan solusi dari kasus terdahulu yang mirip dengan kasus saat baru. Proses mencari kedekatan antara kasus baru dengan kasus lama dapat menggunakan berbagai macam metode, dimana metode ini akan mempengaruhi keberhasilan dari CBR dalam menentukan kasus lama yang paling mirip (Edi F. 2015). Salah satu metode yang dapat digunakan dalam menghitung kemiripan (similarity) adalah nearest neighbor.

Penelitian yang menggabungkan teknik Rule Based Reasoning/RBR dan CBR pernah dilakukan (Labellapansa, A. 2013) untuk membantu penegakan diagnosa gangguan kejiwaan pada manusia. Gangguan kejiwaan yang diteliti adalah jenis skizofrenia. Perhitungan kepastian rule base menggunakan certainty factor sedangkan perhitungan similaritas antara kasus baru dan kasus lama menggunakan teknik retrieval nearest neighbor dengan menambahkan pembobotan (weighted). Pada penelitian ini, rule base hanya digunakan untuk memastikan apakah gejala awal/umum terdapat dalam aturan yang mengarah pada gangguan jiwa. Sedangkan CBR hanya dapat di gunakan setelah di pastikan bahwa gejala awal yang dialami pasien merupakan gejala gangguan jiwa. Sehingga dalam penelitian ini antara RBR dan CBR tidak berjalan bersama-sama dalam menentukan diagnosa.

\section{Rule-Based Reasoning}

Salah satu metode penalaran yang dapat digunakan dalam membangun sebuah sistem pakar adalah metode Rule Based Reasoning (RBR). RBR menggunakan pengetahuan-pengetahuan umum yang dibentuk menjadi serangkaian aturan (rule) sebagai basis pengetahuan untuk menghasilkan solusi yang diinginkan. Dimana sistem pakar (expert system) merupakan suatu perangkat lunak komputer yang memiliki basis pengetahuan untuk domain tertentu dan menggunakan penalaran inferensi menyerupai seorang pakar dalam menyelsaikan masalah (Samsilul A, Herlina L, and Leni N. 2014).

\section{Case-Based Reasoning}

Case-Based Reasoning (CBR) adalah metode untuk menyelesaikan masalah dengan mengingat kejadian-kejadian yang sama/sejenis (similar) yang pernah terjadi di masa lalu kemudian menggunakan pengetahuan/informasi tersebut untuk 
menyelesaikan masalah yang baru, atau dengan kata lain menyelesaikan masalah dengan mengadaptasi solusi-solusi yang pernah digunakan di masa lalu.

\section{Penyakit Ikan}

Ikan merupakan hewan yang hidup di air yang menjadi salah satu dari sekian banyak bahan makanan yang dibutuhkan manusia. Potensi usaha perikanan pun semakin menggiurkan karena budidaya ikan air tawar memiliki kenaikan permintaan dari kebutuhan rata-rata yang ada pada saat ini oleh sebab itu peningkatan produksi ikan air tawar perlu digalakkan (Hence B. L. and S. Hartati. 2015). Perhatian terhadap masalah penyakit ikan berkembang sejalan dengan meningkatnya sistem budidaya ikan ke arah intensifikasi.

Adanya informasi yang memadai mengenai cara mencegah dan mengobati penyakit ikan sangat bermanfaat dalam upaya mempercepat peningkatan pengetahuan petambak/petani ikan yang selama ini masih banyak menggunakan teknologi. Terbatasnya penyebaran informasi mengenai penyakit udang/ikan ke tingkat petambak/petani ikan menyebabkan kesulitan dalam melakukan tindakan penanggulangan maupun cara pengobatan atau terapinya. Selain itu, jika petambak/petani ikan mengalami suatu masalah yang berkaitan dengan penyakit ikan, akan membutuhkan waktu, biaya, dan tenaga yang banyak untuk menghubungi seorang pakar (konsultan) penyakit ikan. Apalagi jika petambak/petani ikan tersebut harus mencari dan membuka buku-buku literatur tentang penyakit ikan. Hal ini sangat menyulitkan dan memakan waktu yang relatif lama, padahal penyakit ikan ini perlu segera ditanggulangi. Salah satu alternatif yang bisa digunakan untuk memecahkan permasalahan tersebut adalah dengan menggunakan alat bantu yang secara otomatis dan cepat bisa melakukan pendiagnosaan dan pemberi informasi cara penanggulangan penyakit ikan.

\section{METODOLOGI PENELITIAN}

\section{Faktor Kepercayaan (Certainty Factor)}

Untuk melakukan perhitungan faktor kepercayaan maka diperlukan pengecekan terhadap sebuah aturan dimana setiap gejala dalam sebuah aturan memiliki nilai kepastian yang berbeda-beda dari pakar. Rancangan mesin inferensi pada sistem ini memungkinkan sistem akan menghasilkan satu buah hasil diagnosa sesuai proses inferensi dan dapat menghasilkan diagnosis penyakit yang kemungkinan diderita oleh ikan jika terdapat aturan lain yang sesuai dengan gejala yang dimasukkan oleh user. Berikut ini Gambar 1 merupakan flowchart menghitung nilai tingkat keyakinan (CF) pada problem baru. 


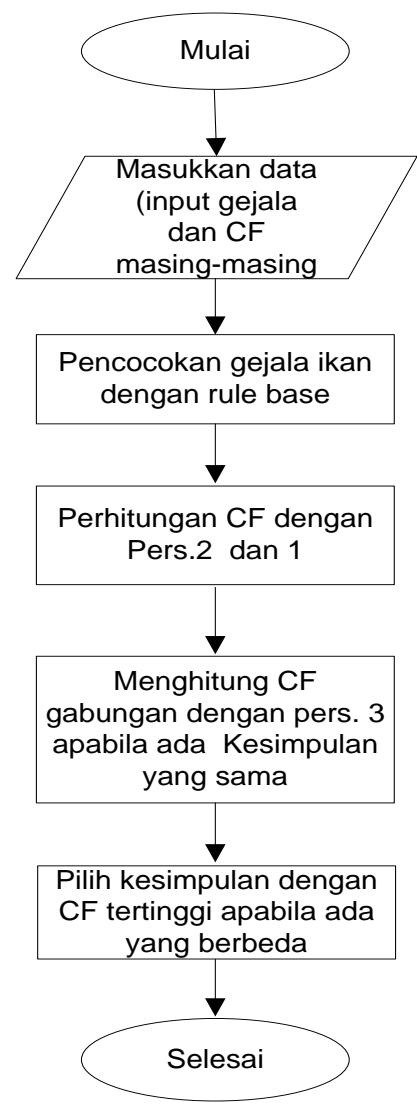

Gambar 1. Flowchart perhitungan certainty factor

Rancangan pada sistem ini memungkinkan sistem akan menghasilkan beberapa aturan (Rule) yang cocok, setelah menghasilkan aturan dilakukan perhitungan nilai tingkat keyakinannya (CF) dengan persamaan (2) dan (1). Hasil dari kesimpulan yang sama akan digabungkan dengan menghitung $\mathrm{CF}$ gabungan dengan persamaan (3) apabila ada kesimpulan yang sama. Selanjutnya memilih kesimpulan dengan CF tertinggi apabila ada kesimpulan yang berbeda.

Persamaan (1) merupakan bentuk dasar rumus CF pada sebuah aturan dalam bentuk IF $\mathrm{E}$ then $\mathrm{H}$ :

$\mathrm{CF}(\mathrm{H}, \mathrm{e})=\mathrm{CF}(\mathrm{E}, \mathrm{e}) * \mathrm{CF}(\mathrm{H}, \mathrm{E})$

Keterangan :

$\mathrm{CF}(\mathrm{E}, \mathrm{e}) \quad=$ Certainty factor $\mathrm{E}$ yang dipengaruhi oleh evidence $\mathrm{e}$.

$\mathrm{CF}(\mathrm{H}, \mathrm{E})=$ Certainty factor dari hipotesis, dengan asumsi bahwa evidence diketahui dengan pasti, yaitu ketika $\mathrm{CF}(\mathrm{E}, \mathrm{e})=1$.

$\mathrm{CF}(\mathrm{H}, \mathrm{e})=$ Certainty factor dari hipotesis berdasarkan ketidakyakinan atas evidence e.

Terdapat beberapa kombinasi certainty factor yang digunakan terhadap berbagai kondisi, yaitu :

1. Certainty factor untuk aturan MYCIN yang digunakan untuk menggabungkan evidence dan anteseden pada suatu kaidah tercantum pada persamaan (2).

$\mathrm{CF}\left(E_{1} A N D E_{2}\right)=\min \left[\mathrm{CF}\left(\mathrm{H}, E_{1}\right), \mathrm{CF}\left(\mathrm{H}, E_{2}\right)\right]$ 
2. Certainty factor untuk kaidah dengan kesimpulan yang serupa (similarity concluded rules), kondisi ini digunakan pada penalaran dimana terdapat lebih dari satu aturan yang menghasilkan hipotesis yang sama namun dengan certainty factor. Persamaan (3) digunakan untuk menghitung nilai CF untuk kaidah dengan kesimpulan yang serupa.

$$
\begin{aligned}
C F_{\text {combinasi }}= & \left\{\begin{array}{l}
c f_{1}+c f_{2}-\left(c f_{1} \cdot c f_{2}\right), \text { jika } c f_{1} \text { dan } c f_{2} \geq 0 \\
\frac{c f_{1}+c f_{2}}{1-\min \left(j k a \text { salah satu } c f_{1} \text { atau } c f_{2}<0\right.}
\end{array}\right. \\
& c f_{1}+c f_{1}|,| c f_{2} \mid
\end{aligned}
$$

\section{Keterangan :}

$$
\begin{array}{ll}
\mathrm{CF}_{\text {combinasi }} & =\text { factor kepastian gabungan } \\
\mathrm{CF}_{1} & =\mathrm{CF} \text { aturan } 1 \\
\mathrm{CF}_{2} & =\mathrm{CF} \text { aturan } 2
\end{array}
$$

\section{Proses Similarity}

CBR didasarkan pada hipotesa bahwa solusi permasalahan-permasalahan sebelumnya dapat membantu penyelesaian permasalahan terkini, sepanjang terdapat kemiripan diantara mereka. Pengukuran kemiripan dilakukan dengan membandingkan fitur yang ada pada kasus dengan fitur sejenis yang ada pada basis kasus. Suatu kasus disebut identik dengan kasus lain apabila nilai similaritasnya sama dengan satu, dan dikatakan mirip jika nilainya dibawah satu. Secara garis besar pengukuran similaritas terdiri dari pengukuran pengukuran similaritas lokal antar atribut kasus dan similaritas global antar kasus (Eka, W. and S. Hartati. 2017). Teknik yang digunakan dalam proses retrieval adalah algoritma nearest neighbor.

Gambar 2 merupakan flowchart untuk menghitung similaritas menggunakan nearest neighbor.

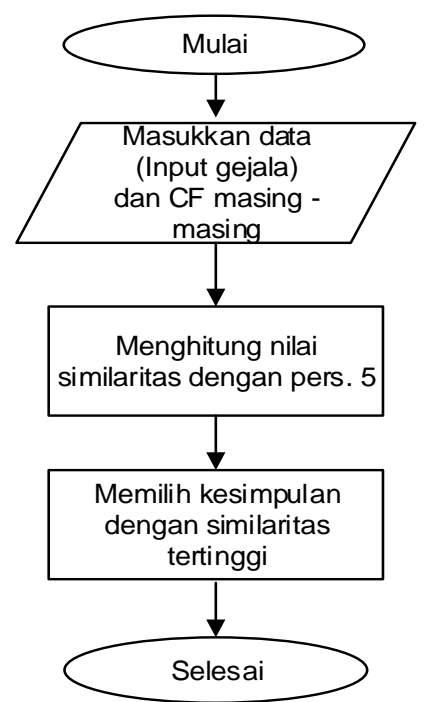

Gambar 2. Flowchart perhitungan Similaritas

Terdapat dua metode utama dalam retrieval dalam CBR yaitu: Global Similarity (Similaritas Global)

Suatu algoritma khusus untuk menghitung nearest neighbor matching yaitu : 
$\operatorname{Sim}(S, T)=\frac{\sum_{i=1}^{n} f\left(S_{i}, T_{i}\right) * w_{i}}{\sum_{i=1}^{n} w_{i}}$

Dimana Sim (S,T) adalah similarity antara kasus $\mathrm{S}$ dan $\mathrm{T}, \mathrm{n}$ adalah jumlah atribut yang ada, $\mathrm{Si}$ adalah atribut ke-i yang ada dalam source case, Ti adalah atribut ke-i yang ada dalam target case, wi adalah bobot atribut ke-i, dimana bobot ini ditentukan oleh pakar dan $\mathrm{f}(\mathrm{Si}, \mathrm{Ti})$ adalah fungsi similarity lokal. Mengingat perbedaan bobot pada fitur untuk setiap kasus dan penanganan gejala baru yang mungkin timbul pada kasus baru, maka rumus pada persamaan (4) diatas perlu dilakukan modifikasi. Modifikasi ini digunakan untuk menangani nilai kepercayaan dan penanganan masalah baru. Modifikasi nearest neighbor yang berhasil mengatasi masalah diatas adalah rumus yang diusulkan oleh (Mancasari, U.K. 2012) sesuai dengan persamaan (5).

Nearest neighbor similarity

$\operatorname{Sim}(S, T)=\left(\frac{\sum_{i=1}^{n} f\left(S_{i}, T_{i}\right) * w_{i}}{\sum_{i=1}^{n} w_{i}}\right) * P(S) * \frac{J(S i, T i)}{J(T i)}$

Keterangan :

$\operatorname{Sim}(S, T) \quad$ : Similarity antara kasus T (target case) dan S (source case)

$n$

$f(S i, T i)$

: Jumlah atribut yang ada

$\mathrm{Ti}$

$\mathrm{Si}$

wi

$P(S)$

: Kesamaan fitur ke-i dari source case dan target case/fungsi similarity lokal

$i$

$J(S i, T i)$

: Atribut ke-i yang ada dalam target case

: Atribut ke-i yang ada dalam source case

: Nilai bobot atribut ke-i

: Persentase tingkat keyakinan pakar terhadap suatu kasus dalam source case

$\mathrm{J}(\mathrm{Ti}) \quad$ : Jumlah gejala yang terdapat dalam target case

Similarity lokal, yaitu similarity yang terdapat pada level fitur

Similarity lokal dibedakan menjadi 2 jenis:

1. Data bernilai numerik

$f(s, t)=1-\frac{|s-t|}{R}$

dimana s,t adalah nilai atribut yang ingin dibandingkan, dan $\mathrm{R}$ adalah range nilai untuk atribut tersebut. Contoh data bernilai numerik pada fitur umur.

2. Data bernilai simbolik :

$$
f(s, t)=\left\{\begin{array}{ll}
1 & \text { jika } s=t \\
0 & \text { lainnya }
\end{array} \text {, dimana } s, t \in\{\text { benar, salah }\}\right.
$$

dimana s adalah source case, $\mathrm{t}$ adalah target case merupakan nilai atribut yang ingin dibandingkan. Contoh data bernilai simbolik pada fitur gejala, misalnya: mata menonjol, perut mengembung, gerakan lemah, pendarahan pada kulit dan lain sebagainya. Pakar akan menentukan nilai bobot Untuk beberapa gejala misalnya gerakan lemah akan diberi nilai bobot sesuai tingkat yang terlihat pada ikan, yaitu : 0 yang berarti gejala tersebut tidak terlihat dan 1 yang berarti gejala tersebut terlihat. 


\section{HASIL DAN PEMBAHASAN \\ Proses Pengujian Sistem}

Data yang digunakan pada saat dilakukan pengujian adalah data yang di peroleh dari Balai Pengembangan Teknologi Kelautan dan Perikanan Argomulyo, Cangkringan, Sleman, Yogyakarta. Penelitian ini memperoleh sebanyak 142 data sampel yang terbagi menjadi dua bagian data yaitu data uji dan data pada basis kasus,sebanyak 30 data uji yang akan digunakan pada sistem ini dan 112 data basis kasus.

Pengujian dilakukan dengan memasukkan data uji satu persatu dengan menggunakan metode rule based dan case based reasoning. Berikut ini adalah jumlah data uji penelitian dari masing - masing jenis penyakit pada Tabel 1.

Tabel 1. Data pengujian

\begin{tabular}{|c|c|c|c|c|c|c|c|}
\hline No & $\begin{array}{l}\text { Jenis } \\
\text { Ikan }\end{array}$ & Gejala & CF User & $\begin{array}{l}\text { Nilai } \\
\text { RBR }\end{array}$ & $\begin{array}{l}\text { Nilai } \\
\text { CBR }\end{array}$ & $\begin{array}{l}\text { Diagnosa } \\
\text { Penyakit }\end{array}$ & $\begin{array}{c}\text { Hasil } \\
\text { gabungan } \\
\text { RBR \& } \\
\text { CBR }\end{array}$ \\
\hline 1 & Patin & $\begin{array}{c}\mathrm{G} 02, \mathrm{G} 04, \mathrm{G} 05 \\
\mathrm{G} 07\end{array}$ & $\begin{array}{c}0.7,0.5 \\
0.8,0.5\end{array}$ & 0.9 & 1 & $\begin{array}{l}\text { Aeromonas } \\
\text { Hydrophila }\end{array}$ & $1(100 \%)$ \\
\hline 2 & Nila & $\begin{array}{c}\text { G01, G05, G06, } \\
\text { G09 }\end{array}$ & $\begin{array}{c}0.5,0.7 \\
0.4,0.3\end{array}$ & 0.86 & 0.52 & $\begin{array}{l}\text { Aeromonas } \\
\text { Hydrophila }\end{array}$ & $\begin{array}{l}0.94 \\
(94 \%)\end{array}$ \\
\hline 3 & Mas & G02, G03, G08 & $\begin{array}{l}0.8,0.8 \\
\quad 0.2\end{array}$ & 0.72 & 1 & $\begin{array}{l}\text { Aeromonas } \\
\text { Hydrophila }\end{array}$ & $1(100 \%)$ \\
\hline 4 & Kerapu & $\mathrm{G} 12, \mathrm{G} 13, \mathrm{G} 14$ & $\begin{array}{c}0.1,0.3 \\
\quad 0.7\end{array}$ & - & 0.44 & Vibrios & $\begin{array}{l}0.44 \\
(44 \%)\end{array}$ \\
\hline 5 & Lele & $\mathrm{G} 20, \mathrm{G} 21$ & $0.3,0.7$ & 0.27 & 0.73 & $\begin{array}{l}\text { Bintik putih } \\
\text { (White Spot) }\end{array}$ & $\begin{array}{l}0.81 \\
(81 \%)\end{array}$ \\
\hline 6 & Koi & G40, G45 & $0.4,0.9$ & - & 0.56 & Gyrodactylosis & $\begin{array}{l}0.56 \\
(56 \%)\end{array}$ \\
\hline 7 & Mas & G16, G40 & $0.3,0.3$ & 0.27 & 0.16 & Saprolegniasis & $\begin{array}{l}0.39 \\
(39 \%)\end{array}$ \\
\hline 8 & Lele & $\mathrm{G} 13, \mathrm{G} 24$ & $0.3,0.8$ & 0.27 & 0.64 & $\begin{array}{l}\text { Trichodiniasis } \\
\text { (Gatal) }\end{array}$ & $\begin{array}{l}0.75 \\
(75 \%)\end{array}$ \\
\hline 9 & Udang & G33, G34 & $0.2,0.7$ & 0.18 & 0.51 & $\begin{array}{l}\text { WSS (White } \\
\text { spot syndrom) }\end{array}$ & $\begin{array}{l}0.6 \\
(60 \%)\end{array}$ \\
\hline 10 & Nila & G26, G27 & $0.9,0.7$ & 0.63 & 1 & Gyrodactylosis & $1(100 \%)$ \\
\hline 11 & Belut & G06, G10, G12 & $0.3,0.8$ & 0.5 & 0.54 & Streptococciosis & 0.77 \\
\hline
\end{tabular}




\begin{tabular}{|c|c|c|c|c|c|c|c|}
\hline No & $\begin{array}{l}\text { Jenis } \\
\text { Ikan }\end{array}$ & Gejala & CF User & $\begin{array}{l}\text { Nilai } \\
\text { RBR }\end{array}$ & $\begin{array}{l}\text { Nilai } \\
\text { CBR }\end{array}$ & $\begin{array}{l}\text { Diagnosa } \\
\text { Penyakit }\end{array}$ & $\begin{array}{c}\text { Hasil } \\
\text { gabungan } \\
\text { RBR \& } \\
\text { CBR } \\
\end{array}$ \\
\hline & & & 0.2 & & & & $(77 \%)$ \\
\hline 12 & Patin & G18, G19, G20 & $\begin{array}{l}0.7,0.5 \\
\quad 0.3\end{array}$ & 0.78 & 0.88 & $\begin{array}{l}\text { Bintik putih } \\
\text { (White Spot) }\end{array}$ & $\begin{array}{l}0.98 \\
(98 \%)\end{array}$ \\
\hline 13 & Udang & G08, G17, G41 & $\begin{array}{l}0.1,0.2 \\
\quad 0.8\end{array}$ & 0.25 & 0.86 & IHHN & $\begin{array}{l}0.9 \\
(90 \%)\end{array}$ \\
\hline 14 & Kerapu & G14, G15 & $0.7,0.7$ & - & 0.63 & Vibrios & $\begin{array}{l}0.63 \\
(63 \%)\end{array}$ \\
\hline 15 & Gurami & G39, G16, G40 & $\begin{array}{l}0.8,0.1 \\
0.2\end{array}$ & 0.38 & 0.69 & Saprolegniasis & $\begin{array}{l}0.81 \\
(81 \%)\end{array}$ \\
\hline 16 & Lele & $\begin{array}{c}\mathrm{G} 13, \mathrm{G} 16, \mathrm{G} 43, \\
\mathrm{G} 23\end{array}$ & $\begin{array}{l}0.2,0.1 \\
0.6,0.7\end{array}$ & 0.82 & 0.63 & $\begin{array}{l}\text { Trichodiniasis } \\
\text { (Gatal) }\end{array}$ & $\begin{array}{l}0.94 \\
(94 \%)\end{array}$ \\
\hline 17 & Udang & G35, G34, G04 & $\begin{array}{l}0.2,0.1 \\
0.6\end{array}$ & 0.51 & 0.22 & $\begin{array}{l}\text { WSS (White } \\
\text { spot syndrom) }\end{array}$ & $\begin{array}{l}0.62 \\
(62 \%)\end{array}$ \\
\hline 18 & Belut & G12, G11, G04 & $\begin{array}{l}0.2,0.1 \\
0.6\end{array}$ & 0.32 & 0.29 & Streptococciosis & $\begin{array}{l}0.52 \\
(52 \%)\end{array}$ \\
\hline 19 & Udang & G17, G41, G08 & $\begin{array}{l}0.1,0.9 \\
0.2\end{array}$ & 0.25 & 0.89 & IHHN & $\begin{array}{l}0.92 \\
(92 \%)\end{array}$ \\
\hline 20 & Gurami & G09, G04 & $0.9,0.4$ & 0.36 & 0.64 & $\begin{array}{l}\text { Pseudomonas } \\
\text { septicemia }\end{array}$ & $\begin{array}{l}0.77 \\
(77 \%)\end{array}$ \\
\hline 21 & Mas & $\mathrm{G} 28, \mathrm{G} 23$ & $0.3,0.8$ & 0.27 & 0.57 & Dactylogyrosis & $\begin{array}{l}0.69 \\
(69 \%)\end{array}$ \\
\hline 22 & Koi & G29, G31, G06 & $\begin{array}{l}0.7,0.8 \\
0.4\end{array}$ & 0.90 & 0.56 & KHV & $\begin{array}{l}0.96 \\
(96 \%)\end{array}$ \\
\hline 23 & Patin & G07, G08, G09 & $\begin{array}{l}0.5,0.2 \\
0.4\end{array}$ & 0.66 & 0.43 & $\begin{array}{l}\text { Pseudomonas } \\
\text { septicemia }\end{array}$ & $\begin{array}{l}0.81 \\
(81 \%)\end{array}$ \\
\hline 24 & Nila & G09, G02, G07 & $\begin{array}{l}0.2,0.4 \\
0.6\end{array}$ & 0.64 & 0.72 & $\begin{array}{l}\text { Pseudomonas } \\
\text { septicemia }\end{array}$ & $\begin{array}{l}0.9 \\
(90 \%)\end{array}$ \\
\hline
\end{tabular}




\begin{tabular}{|c|c|c|c|c|c|c|c|}
\hline No & $\begin{array}{l}\text { Jenis } \\
\text { Ikan }\end{array}$ & Gejala & CF User & $\begin{array}{l}\text { Nilai } \\
\text { RBR }\end{array}$ & $\begin{array}{l}\text { Nilai } \\
\text { CBR }\end{array}$ & $\begin{array}{l}\text { Diagnosa } \\
\text { Penyakit }\end{array}$ & $\begin{array}{c}\text { Hasil } \\
\text { gabungan } \\
\text { RBR \& } \\
\text { CBR }\end{array}$ \\
\hline 25 & Lele & G43, G28, G26 & $\begin{array}{c}0.6,0.2 \\
0.8\end{array}$ & 0.85 & 0.55 & Dactylogyrosis & $\begin{array}{l}0.94 \\
(94 \%)\end{array}$ \\
\hline 26 & Gurami & G32, G05 & $0.3,0.9$ & - & 0.67 & KHV & $\begin{array}{l}0.67 \\
(67 \%)\end{array}$ \\
\hline 27 & Patin & G41, G12 & $0.7,0.1$ & - & 0.52 & Mycosis & $\begin{array}{l}0.52 \\
(52 \%)\end{array}$ \\
\hline 28 & Belut & $\begin{array}{c}\text { G11, G10, G06, } \\
\text { G08 }\end{array}$ & $\begin{array}{c}0.5,0.4 \\
0.2,0.1\end{array}$ & 0.70 & 0.27 & Streptococciosis & $\begin{array}{l}0.79 \\
(79 \%)\end{array}$ \\
\hline 29 & Koi & G45, G16 & $0.9,0.3$ & 0.27 & 0.56 & Gyrodactylosis & $\begin{array}{l}0.68 \\
(68 \%)\end{array}$ \\
\hline 30 & Gurami & G07, G10, G01 & $\begin{array}{c}0.6,0.3 \\
0.3\end{array}$ & - & 0.54 & $\begin{array}{l}\text { Pseudomonas } \\
\text { septicemia }\end{array}$ & $\begin{array}{l}0.48 \\
(48 \%)\end{array}$ \\
\hline
\end{tabular}

Tabel 1 merupakan hasil dari proses perhitungan dari penggabungan nilai RBR dan CBR, pengujian sistem dengan menggunakan data uji sebanyak 30 kasus dengan jumlah data diagnosa benar sebanyak 24 sedangkan 6 data dengan nilai similaritas di bawah nilai threshold, kasus yang menghasilkan diagnosa dengan nilai similarity di bawah nilai threshold akan dilakukan revisi oleh pakar penyakit ikan, untuk memperoleh solusi yang tepat sesuai dengan gejala yang muncul pada ikan.

\section{Proses Evaluasi Sistem}

Proses evaluasis hasil pengujian sistem dalam mendiagnosa penyakit ikan dilakukan dengan menghitung nilai akurasi. Evaluasi sistem penting dilakukan untuk mengetahui apakah sistem yang telah dibangun layak diterapkan dalam mendiagnosa penyakit ikan untuk menghitung nilai akurasi sistem dapat dilakukan dengan menggunakan persamaan (8). Akurasi sistem $=\frac{24}{30} \times 100 \%=80 \%$.

Hasil perhitungan di atas menunjukkan bahwa tingkat akurasi sistem dalam mengenali penyakit ikan sebesar $80 \%$.

\section{KESIMPULAN}

Berdasarkan penelitian dan hasil pengujian yang telah dilakukan, maka dapat disimpulkan bahwa, data yang digunakan pada penelitian ini sebanyak 142 data yang terdiri dari 112 data sebagai basis kasus dan 30 data sebagai data uji, hasil pengujian menunjukkan bahwa sistem mengenali 24 data yang sesuai dengan data riil hasil diagnosa pakar dan 6 data yang tidak sesuai dengan data riil hasil diagnosa pakar atau bisa dikatakan nilai akurasi sistem sebesar $80 \%$.Makassar-Maros adalah 44,67 menit untuk Sepeda Motor dan 54,00 menit untuk Kendaraan Ringan. 


\section{DAFTAR PUSTAKA}

Afrianto, E., Liviawaty, E., Jamaris, Zafran., dan Hendi. (2015). Buku Penyakit Ikan Cetakan 1, Jakarta: Penerbit Penebar Swadaya.

Anggraeni, T. D., Qomariyah dan Khalidah. (2015). Penyebaran dan Budidaya Ikan Air Tawar di Pulau Jawa Berbasis Web. Fakultas Ilmu Komputer dan Teknologi Informasi. Universitas Gunadarma, Bekasi, Jawa Barat, ISBN 978602-993344-4,[online].

Available:http://download.portalgaruda.org/article.php?article $=352914 \&$ val $=5$ 634\&title=PENYEBARAN\%20DAN\%20BUDIDAYA\%20IKAN\%20AIR\%2 0TAWAR\%20DI\%20PULAU\%20JAWA\%20\%20BERBASIS\%20WEB. [Accessed: 24-Oktober-2017].

Aristoteles, Wardiyanto dan Ardye Amando Pratama. (2015).Sistem Pakar Diagnosa penyakit Pada Ikan Budidaya Air Tawar dengan Metode Forward Chaining, Jurnal Komputasi Ilmu Komputer Unila Publishing Network All Right Reserved,Vol.3,No.2,[online].

Available: http://jurnal.fmipa.unila.ac.id/index.php/komputasi. [Accessed: 21September-2017].

Edi F. (2015). Integrasi Case-Based Reasoning dan Rule-Based Reasoning untuk Pengembangan Sistem Pendeteksi Dini Gangguan Tumbuh Kembang Anak. Program Studi Manajemen Informatika STMIK El Rahma, Yogyakarta, Vol. 13, No. 3. [online].

Available:http://jurnal.stmikelrahma.ac.id/assets/file/Edi\%20Faizal-28stmikelrahma.pdf. [Accessed: 21-September-2017].

Eka, W. and S. Hartati. (2017). Case-Based Reasoning Untuk Diagnosis Penyakit Jantung. Tesis, vol. 11, No. 1, 2017. [online].

Available: https://jurnal.ugm.ac.id/ijccs/article/view/15523/11717. [Accessed: 20-July-2017].

Hence B. L. and S. Hartati. (2015). Sistem Pendukung Keputusan untuk Memilih Budidaya Ikan Air Tawar Menggunakan Af-Topsis. Vol. 9, No. 2, ISSN: 1978-1520.[online].

Available: https://jurnal.ugm.ac.id/ijccs/article/view/7548/5871, [Accessed: 1 Oktober 2017].

Labellapansa, A. (2013). Implementasi Penalaran Berbasis Aturan dan Berbasis Kasus untuk Diagnosa Gangguan Kejiwaan Psikosis. Tesis, S2 Ilmu Komputer UGM, Yogyakarta.

Made, H.P.S, and E. Winarko. (2011).Sistem Diagnosis Penyakit Gigi dan Mulut Menggunakan Kombinasi Case Based Reasoning dan Rule Based Reasoning. Tesis, Program Pasca Sarjana Ilmu Komputer, Univ. Gadjah Mada, Yogyakarta.

Mancasari, U.K. (2012). Sistem Pakar Menggunakan Penalaran Berbasis Kasus Untuk Mendiagnosa Penyakit Saraf Pada Anak. Skripsi. Prodi S1 Ilmu Komputer, Universitas Gadjah Mada, Yogyakarta.

Samsilul A, Herlina L, and Leni N. (2014). Sistem Pakar Penyakit Ginjal Pada Manusia menggunakan Metode Forward Chaining. Jurnal Media Infotama, Vol. 10, No.1, ISSN 1858-2680. [online].

Available: http://jurnal.unived.ac.id/index.php/jmi/article/download/228/205. [Accessed: 21-September-2017]. 